\title{
Pro-ELT; A Teacher Training Blended Approach
}

\author{
Reza Eshtehardi \\ The British Council Malaysia, Pro-ELT \\ Ground Floor, West Block, Wisma Selangor Dredging 142C Jalan Ampang 50450 Kuala Lumpur \\ E-mail: eshtehardi8@gmail.com
}

Doi:10.7575/aiac.alls.v.5n.5p.106

URL: http://dx.doi.org/10.7575/aiac.alls.v.5n.5p.106
Received: 02/07/2014

Accepted: 28/08/2014

The research is financed by the British Council Malaysia.

\begin{abstract}
Pro-ELT is a blended teacher training course. The aim of Pro-ELT is to strengthen English teaching and learning through a blended training approach that includes; quality face to face delivery, supported distance learning and integrated proficiency and methodology training. It delivers quality language teaching and teacher development courses to Malaysian primary and secondary school teachers working in Malaysian government schools in order to develop their English language proficiency and teaching knowledge and skills. Language skills and system are undoubtedly the basic components of each teacher training program, but there is a fact that for a huge number of non-native language teachers who teach at school levels, improving their own language proficiency and command of English is their own personal objective and top priority in their professional development. This presentation shows the Pro-ELT model of teacher training program and shows how teachers will be able to achieve their professional development goals.
\end{abstract}

Keywords: Blended learning, face to face trainer, E-moderator, Aptis

\section{Introduction}

Almost all teacher training courses for non-native English language teachers have predictable components. They normally offer a blend of language skills training e.g. how to teach writing or speaking, and language systems e.g. grammar, discourse and phonology. In general one of the most important components of such courses is classroom teaching methodology. In other words all the techniques and skills teachers need to equip themselves for classroom situations. Another component of training courses is the linguistic component which mainly highlights the theories of language and language learning. The objective of this component is mainly to raise teachers awareness of the nature of English and how it works rather than how to us it. Depending on the nature of the training course there are often other components such as the classical aspect of English or the use of technology in language teaching. But what is missing in almost all training courses is the language improvement component. Non-native language teachers need to improve their language proficiency so they can use proper English in their classroom. This component is important, as Wills (1981) mentions, because it has a direct link with classroom language and teachers instructions in class. With the increasing acceptance of the principles of communicative language teaching around the globe, there is more pressure on teachers to be more fluent in English so that they can use it naturally in the classroom presenting a reliable model for their learners. Nowadays on-line courses are growing rapidly in almost all fields, giving a flexible option to those who are interested in education but are not able to allocate specific time to study regularly. On-line teacher training programs have been increasing rapidly along with other field of studies. Rogers (2000) has mentioned that on-line teacher training and development is a practical proposition due to developments in IT. The focus of this paper is to highlight the blended nature and the language improvement component of the Pro-ELT project for Malaysian primary and secondary language teachers.

\section{What is Pro-ELT?}

The primary objectives of the Pro-ELT (Professional Development Programme for English Language Teachers) project are to strengthen the Malaysian primary and secondary school teachers' English language proficiency, language teaching and learning through a blended training approach that includes: face to face training supported on-line learning and integrated proficiency and methodology training. In 2003 The British Council successfully completed a one year pilot project with the Malaysian Ministry of Education with 5000 Malaysian English Language teachers. The second year of the project consists of training 9000 Malaysian primary and secondary school English teachers in partnership with the Malaysian Ministry of Education. Pro-ELT trainers deliver language proficiency training to teachers working in Malaysian government schools using the British Council global materials. Each class is also assigned an on-line trainer (E-moderator) to manage and facilitate on-line training. In total there are 480 hours of face to face and on-line training per year, per teacher. 


\section{What is Aptis?}

Aptis is the British Council global English assessment tool. It is an English test to assess the ability of adults and young adults in all four English skills, grammar and vocabulary. Pro-ELT Aptis is an on-line test, but there are also pen \& paper versions as well. Aptis is not designed to test a single level. It is to demonstrate the ability of the candidates in different contexts. The results of the test are reported for each of the four skills as a Common European Framework of Reference for languages (CEFR) level ranging from A1 to C2. As it is mentioned in the Aptis Advanced Candidate Guide (2014) Aptis is not a recognized test like IELTS or TOEFL. It is not recognized by universities, educational institutions or embassies as proof of language proficiency, but it is designed to be used within institutions and for internal purposes. O'Sullivan (2011) mentions that Aptis is based on the socio-cognitive framework test validation theory in modern assessment. This theory focuses on how three elements of the test taker, the test system and the scoring system combine to give a measure of a candidate's performance which relates meaningfully to their ability in English. The theoretical model of test validation which drives the Aptis test system is based on the modifications to the Weir (2005) model suggested by O'Sullivan (2011) and O'Sullivan and Weir (2011). O'Sullivan (2012) has stressed that Aptis is not a static system. It has been designed to change over time to reflect current research in second language acquisition, applied linguistics, and assessment. This philosophy is reflected in the whole approach taken, from the planning to designing of the test items. Malaysian teachers take the Aptis test twice during the course as placement and end of the course tests.

\section{Materials}

Various resources are used in Pro-ELT to respond to different needs and wants of teachers at different stages of their professional development. English for Teaching (EFT) is the main course book material. EFT is designed and published by the British Council. It is a comprehensive training course for practicing teachers who need to develop their language proficiency as well as teaching skills. There are three levels of EFT; EFT1, EFT2 and EFT3 to accommodate teachers with different language proficiency from $\mathrm{A} 2$ to $\mathrm{C} 1$ based on CEFR. EFT combines language acquisition with developing communicative skills and classroom methodology. All the contexts are familiar to teachers and relate the target language to those contexts. There are varied tasks and activities for each context to enable teachers to develop all four skills as well as teaching and reflective skills. The course also includes a Development Journal (DJ). As mentioned in the EFT trainer's guide (2012); the DJ has two main objectives, which are to provide participants with the opportunity to: Demonstrate their understanding of the learning aims of the main module and Personalise the content of the main module.

EFT follows a learner- centered approach which includes communicative methodology as well as opportunities for language awareness. Some key features of EFT as mentioned in the EFT trainer's guide (2012) are:

1.1 Contextuaised language input and practice,

1.2 Opportunities to relate content to participants' own teaching situations,

1.3 Analysis of target language items,

1.4 Focus on common learner mistakes to determine underlying causes,

1.5 Communicative skills development through pair and group work,

1.6 Exposure to different teaching techniques and methods,

1.7 Reflective activities to facilitate learning and improve teaching.

Each course provides approximately 120 hours of training. Table 1 shows the make-up of the EFT3 syllabus.

Table 1. EFT3 syllabus

\begin{tabular}{|c|c|c|c|c|c|c|c|c|c|c|}
\hline Module & $\begin{array}{l}\text { Language } \\
\text { development }\end{array}$ & $\begin{array}{l}\text { Language } \\
\text { in context }\end{array}$ & Task & Pronunciation & Methodology & $\begin{array}{l}\text { In the } \\
\text { classroom }\end{array}$ & Magazine & Vocabulary & Activity & Reflection \\
\hline $\begin{array}{l}\text { 3. For or } \\
\text { against }\end{array}$ & $\begin{array}{l}\text { "ing" forms, } \\
\text { infinitives } \\
\text { and linkers }\end{array}$ & $\begin{array}{l}\text { Arguments } \\
\text { for and } \\
\text { against }\end{array}$ & $\begin{array}{l}\text { Student } \\
\text { fees }\end{array}$ & $\begin{array}{l}\text { Stress for } \\
\text { emphasis }\end{array}$ & Project work & $\begin{array}{l}\text { Planning a } \\
\text { project }\end{array}$ & $\begin{array}{l}\text { Project } \\
\text { work with } \\
\text { teenagers }\end{array}$ & $\begin{array}{l}\text { Project } \\
\text { words }\end{array}$ & $\begin{array}{l}\text { Tic tac } \\
\text { toe }\end{array}$ & $\begin{array}{l}\text { Pyramid } \\
\text { discussion }\end{array}$ \\
\hline
\end{tabular}

Teachers cover two aspects of EFT during the course; one is face to face classroom training and the other one is on-line training.

\section{On-line training component}

The on-line training complements the face to face training and helps teachers improve their English language proficiency as well as teaching methodology. The platform for the on-line component is Moodle and the content of the course is English for Teaching (EFT) at either B1 or B2 level. It takes 240 hours for teachers to complete this moderated on-line course. Some unique features of the on-line component are exercises, reading material, forums, wikis and assignments. Forums and wikis are essential parts of on-line learning, enabling teachers to collaboratively build knowledge, create group cohesion and learn from each other. There are 18 modules which open and close according to a schedule throughout the year and teachers go through the course in their free time. In order to keep teachers in the same place, only one module opens at a time. Once a module closes, teachers can go back and view the materials but they cannot work on it. There is an on-line trainer (E-moderator) for each class to moderate the on-line learning. There are 
many opportunities for teachers to interact with other teachers as well as their E-moderators in order to improve their language proficiency in components such as forums, wikis and assignments. Here is a list of possible on-line activities:

a. Forums: A large part of the learning takes place here by sharing ideas and experiences. Teachers are required to contribute to discussions regularly. They are required to:

i. Post in each discussion,

ii. Make comments on other teachers' posts,

iii. Share their ideas, experiences and opinions.

b. Wikis: Wikis are used when teachers work together to make one document. Teachers can add, change or edit in the wiki. They are required to:

i. Post in each wiki,

ii. Edit other teachers' comments if necessary,

iii. Share their ideas, experiences and opinions.

c. Exercises: There are various tasks and exercises in each module to create opportunities for teachers to practice the target language. These are not designed to test teachers, but to be a way of teaching. Most exercises let teachers go back and try again.

d. Assignments: The objective of the assignments is to help teachers develop their language proficiency and create an opportunity to receive feedback from the E-moderator on their language.

i. Six assignments in total over the course,

ii. Assignments are quick to complete,

iii. Assignments are not a test - instead they should help teachers review what they've learnt and identify areas to work on.

In addition to the EFT on-line work, teachers also need to complete Learn English Pathways courses (B1: Self-study Intermediate 1 and 2, B2: Self Study Upper-intermediate 1 and 2). These are self access (there is no moderator) and should take around 60 hours. The focus here is more on grammar and vocabulary.

\section{Teachers' needs analysis}

This sections is based on the outcome of a questionnaire I conducted with four groups of primary and secondary school teachers in 2013 in Malaysia, asking them to highlight whether they needed to improve their language awareness, theories of language learning/teaching, teaching methodology or language proficiency during the Pro-ELT project. For all groups language proficiency was ranked as the most important. Teaching methodology and language awareness came second and third. Teachers did not indicate a great interest in theories of language learning/teaching. Based on the teachers' background education and the educational system in which teachers are working, the language proficiency outcome is justifiable. Here is a brief analysis of the primary reasons given by the teachers for teachers wanting to focus on improving their language proficiency:

e. Malaysia is a multi-cultural country and people speak a variety of languages. For most people, especially in rural areas, English is a totally foreign language with limited exposure to and access to authentic language.

f. English is taught as a compulsory course in the primary and secondary school curriculum. Currently it is not used as the medium of instruction at any level.

g. Having an English teaching qualification and training is not essential for teachers to teach English.

h. Teachers' exposure to English is quite limited. The previous experience of formal exposure to English for some teachers dates back from the time they were students at school.

i. The language of instruction in English classes is not normally English. Teachers believe that it is confusing for students if teachers give instructions in English. On the hand some teachers also feel that they are not proficient enough to teach English using English all the time.

j. Communicative teaching methodology and strategies require teachers to have high level language proficiency and be ready to respond to any emerging needs of students. Marton (1988) clearly mentions that 'communicative strategy' requires teachers 'to be prepared for any linguistic emergency'.

\section{Blended learning}

"Blended learning refers to a language course which combines a face to face (F2F) classroom component with an appropriate use of technology. The term technology covers a wide range of recent technologies, such as the Internet, CD ROMs and interactive whiteboards, it also includes the use of computers as a means of communication such as chat and email, and a number of environments which enable teachers to enrich their courses, such as VLEs (virtual learning environments), blogs, and wikis" (Sharma \& Barrett, 2007, pp: 7). For many, blended learning is "nothing new" (Claypole, 2003). Sharma \& Barrett, (2007) believe that a blended-learning course run without a principled approach may be considered as an 'eclectic' blending together of course components, and can end up as rather a mish-mash.

Pro-ELT is designed based on a blended learning approach; 50\% of the course is F2F and $50 \%$ on-line. The two components of Pro-ELT fully complement each other. Carefully chosen on-line materials enhance the F2F component 
of the course, teachers have the opportunity to work at their own pace and in their own free time. F2F trainers and Emoderators cooperate closely to facilitate learning and find solutions for teachers emerging needs. Teachers have many opportunities to improve their language proficiency based on their learning styles and preferences. Here are some important features of Pro-ELT:

k. the use of technology is motivating for teachers,

1. the interactivity of language exercises is beneficial,

m. teachers receive different types of feedback from their trainers, E-moderators and peers,

n. instant feedback offered by Moodle on exercises is quite helpful,

o. teachers with different learning styles can find their preferred activities,

p. activities are practical so teachers can implement them in their own lessons,

q. the use of technology can make teachers more autonomous,

r. teachers have many opportunities to discuss their professional issues with trainers and other teachers,

Figure 1. shows the connection between the F2F \& On-line components and different stages of training in Pro-ELT.

- Diagnostic stage: E-moderators and trainers diagnose teachers' strengths and weaknesses.

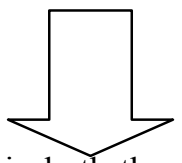

- Training stage: Springboard to more input in both the on-line and face to face components. For example: Speaking skills developed in the face to face context. Feedback is given to teachers and relayed to their emoderator.

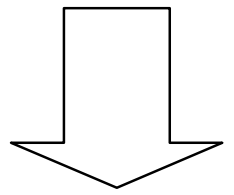

- Practice stage: Face to face: Interactive activities in class: group work, feedback etc. Reflective activities online: moderated forums, vocabulary building, listening tasks etc.

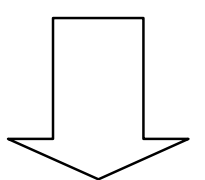

- Production stage: Production tasks set in both contexts.

Face to face: dialogues, presentations, mini teaching tasks etc.

On-line: individual assignments, voice recording, chartrooms, webinars etc.

Figure 1. Connection between the F2F \& On-line components

\section{Some considerations}

Better understanding of the Malaysian school teachers and the contexts they are working at will facilitate the training and give everyone who is involved in the project a clear picture of teachers' and students' essential needs. Here are some considerations that need to be taken into account.

s. The primary objectives of the project are to improve the language proficiency and teaching methodology of the Malaysian school teachers so they can confidently teach their classes. However, what students and parents expect from teachers is to prepare students for end of the term and national examinations which turn a general English class into an exam class. Consequently, teachers pay closer attention to exam related language features of Pro-ELT than general linguistics features. For instance pronunciation receives less attention and effort from teachers as it is not a top priority in school examinations.

t. Teachers may have positive, negative or neutral attitudes towards technology. Attitudes towards technology play an important role in Pro-ELT as teachers spend substantial amounts of time on-line. Trainers and E-moderators have a key role here to create positive attitudes among teachers since having an acceptable knowledge of technology will make teachers more autonomous and independent in the process of improving language proficiency.

u. On-line component must enhance F2F training and not to make teachers' job more complicated as ultimately teachers are required to teach F2F classes. The course must enable teachers to focus on the pedagogical aspects of the course in order to achieve their objectives. Achieving the objectives in Pro- 
ELT might be unrealistic if course participants do not feel comfortable with the on-line component due to lack of on-line training or interest in technology. On the other hand, Aptis is an on-line assessment which is the final test in Pro-ELT so teachers need to feel comfortable being assessed using an on-line test.

v. As Pro-ELT is an in-service training course for practicing teachers whose language proficiency is below $\mathrm{C} 1$, meaning teachers with a $\mathrm{C} 1$ level of proficiency are not required to attend the course, it seems necessary to make it clear that this is an opportunity for those who attend the course to upgrade their language proficiency as well as teaching methodology and the other objectives of a blended

\section{Conclusion}

training course and that Pro-ELT is not merely a general language proficiency class.

I have tried in this paper to look at different components of Pro-ELT and highlight the blended nature of this teacher training course. Normally teacher training courses for non-native English language teachers around the world have predictable components such as language awareness, theories of language learning/teaching and teaching methodology. Improving teachers' command of English is not directly addressed in such training. The primary objectives of Pro-ELT are to improve teachers' command of English as well as teaching methodology and classroom strategies. Pro-ELT combines F2F and on-line components to facilitate training for different teachers with different learning styles and workloads. Pro-ELT enables teachers to use new methodologies and strategies in their own classes and reflect on their own teaching which is crucial for their continued professional development that will be more successful and have a greater impact in the classroom if teachers meet their personal goal of improving their English language proficiency.

\section{References:}

Aptis Advanced Candidate Guide. (2014). The British Council.

EFT trainer's guide. (2012). The British Council.

Claypole, M. (2003). Blended Learning: new resources for teaching Business English. In Pulverness, A. (ed.)IATEFL Brighton Conference Selections.

Marton, W. (1988). Methods in English Language Teaching. New York: Prentice Hall.

O’Sullivan, B. (2012). Aptis Test Development Approach, the British Council.

O'Sullivan, B and Weir, C. (2011). Language Testing and Validation, in Barry O'Sullivan (ed) Language Testing: Theory and Practice (pp. 13-32). Oxford: Palgrave.

Rogers, P \& Coles, T. (March 2000). Online teacher training.

Sharma, P \& Barrett, B. (2007). Blended Learning, Macmillan

Willis, J. (1981). Teaching English through English. Harlow: Longman. 